\title{
Response to 'Ramipril attenuates lipid peroxidation and cardiac fibrosis in an experimental model of rheumatoid arthritis' - authors' reply
}

\author{
Qin Shi, Jamilah Abusarah, Ghayath Baroudi, Julio C Fernandes, Hassan Fahmi and Mohamed Benderdour* \\ See related research by Shi et al., http://arthritis-research.com/content/14/5/R223, and related letter by Wang et al., \\ http://arthritis-research.com/content/15/2/405
}

We thank Wang and colleagues for their comments [1] about our recent study [2] and would like to make two points to clarify our reasoning.

First, in our study [2], female Lewis rats have been used in order to induce arthritis. This experimental model of arthritis was well described in our previous study published in Molecular Therapy [3]. Actually, a number of researchers use male or female animals to induce arthritis. For example, the use of female rats to induce arthritis has been reported in several recent articles [4-11]. In our unpublished data, we have shown that (a) adjuvant most likely induces arthritis equally in female and male Lewis rats and (b) female and male Lewis rats with arthritis have similar levels of lipid peroxidation products and cardiac fibrosis markers in heart tissues. These data were obtained by using a small cohort of male Lewis rats $(n=3)$, and we are keeping in mind that additional experiments will be performed in a future project of ours with a large cohort of male rats.

Second, in our recent study [2], female Lewis rats with arthritis received ramipril (10 $\mathrm{mg} / \mathrm{kg}$ per day). The dose of this drug was chosen from the literature [12-14].

\section{Competing interests}

The authors declare that they have no competing interests.

Published: 3 April 2013

\section{References}

1. Wang D, Hu S, Wei W: Response to 'Ramipril attenuates lipid peroxidation and cardiac fibrosis in an experimental model of rheumatoid arthritis'. Arthritis Res Ther 2013, 15:405.

2. Shi Q, Abusarah J, Baroudi G, Fernandes JC, Fahmi H, Benderdour M: Ramipril attenuates lipid peroxidation and cardiac fibrosis in an experimental model of rheumatoid arthritis. Arthritis Res Ther 2012, 14:R223.

3. Fernandes JC, Wang H, Jreyssaty C, Benderdour M, Lavigne P, Qiu X, Winnik FM, Zhang X, Dai K, Shi Q: Bone-protective effects of nonviral gene therapy

*Correspondence: mohamed.benderdour@umontreal.ca

Orthopaedics Research Laboratory, Hôpital du Sacré-Cœur de Montréal and Department of Surgery, Université de Montréal, 5400 Gouin Boulevard West, Montreal, QC, H4J 1C5, Canada with folate-chitosan DNA nanoparticle containing interleukin-1 receptor antagonist gene in rats with adjuvant-induced arthritis. Mol Ther 2008, 16:1243-1251.

4. LuY, Stinnette TW, Westrick E, Klein PJ, Gehrke MA, Cross VA, Vlahov IR, Low PS, Leamon CP: Treatment of experimental adjuvant arthritis with a novel folate receptor-targeted folic acid-aminopterin conjugate. Arthritis Res Ther 2011, 13:R56.

5. Coulthard LG, Costello J, Robinson B, Shiels IA, Taylor SM, Woodruff TM: Comparative efficacy of a secretory phospholipase A2 inhibitor with conventional anti-inflammatory agents in a rat model of antigen-induced arthritis. Arthritis Res Ther 2011, 13:R42.

6. Du F, Lü L, Fu Q, Dai M, Teng JL, Fan W, Chen SL, Ye P, Shen N, Huang XF, Qian J, Bao CD: T-614, a novel immunomodulator, attenuates joint inflammation and articular damage in collagen-induced arthritis. Arthritis Res Ther 2008, 10:R136.

7. Le Goff B, Soltner E, Charrier C, Maugars Y, Rédini F, Heymann D, Berthelot JM: A combination of methotrexate and zoledronic acid prevents bone erosions and systemic bone mass loss in collagen induced arthritis. Arthritis Res Ther 2009, 11:R185.

8. Boettger MK, Leuchtweis J, Kümmel D, Gajda M, Bräuer R, Schaible HG: Differential effects of locally and systemically administered soluble glycoprotein 130 on pain and inflammation in experimental arthritis. Arthritis Res Ther 2010, 12:R140.

9. Ahmed AS, Li J, Ahmed M, Hua L, Yakovleva T, Ossipov MH, Bakalkin G, Stark A: Attenuation of pain and inflammation in adjuvant-induced arthritis by the proteasome inhibitor MG132. Arthritis Rheum 2010, 62:2160-2169.

10. Lauzier A, Charbonneau M, Harper K, Jilaveanu-Pelmus M, Dubois CM: Formation of invadopodia-like structures by synovial cells promotes cartilage breakdown in collagen-induced arthritis: involvement of the protein tyrosine kinase Src. Arthritis Rheum 2011, 63:1591-1602.

11. Clark AK, Grist J, Al-Kashi A, Perretti M, Malcangio M: Spinal cathepsin S and fractalkine contribute to chronic pain in the collagen-induced arthritis model. Arthritis Rheum 2012, 64:2038-2047.

12. Berkenboom G, Langer I, Carpentier Y, Grosfils K, Fontaine J: Ramipril prevents endothelial dysfunction induced by oxidized low-density lipoproteins: a bradykinin-dependent mechanism. Hypertension 1997, 30 (3 Pt 1):371-376.

13. Moinuddin G, Inamdar MN, Kulkarni KS, Kulkarni C: Modulation of hemodynamics, endogenous antioxidant enzymes, and pathophysiological changes by Angiotensin-converting enzyme inhibitors in pressure-overload rats. Hellenic J Cardiol 2011, 52:216-226.

14. Raasch W, Jöhren O, Schwartz S, Gieselberg A, Dominiak P: Combined blockade of AT1-receptors and ACE synergistically potentiates antihypertensive effects in SHR. J Hypertens 2004, 22:611-618.

\section{doi:10.1186/ar4196}

Cite this article as: Shi Q, et al:: Response to 'Ramipril attenuates lipid peroxidation and cardiac fibrosis in an experimental model of rheumatoid arthritis' - authors' reply. Arthritis Research \& Therapy 2013, 15:406. 